\title{
Pengaruh Penggunaan Facebook Pada Pembelajaran dengan Model Problem Posing terhadap Hasil Belajar Stoikiometri
}

\author{
Shinta Amalia 1 \\ ${ }^{1}$ Pendidikan Kimia-Universitas Negeri Malang
}

\section{INFO ARTIKEL}

\section{Riwayat Artikel:}

Diterima: 10 juni 2019

Disetujui: 11 Oktober 2019

\section{Kata kunci:}

Facebook

Problem posing

Hasil belajar

Stoikiometri

\author{
Alamat Korespondensi: \\ Shinta Amalia \\ Pendidikan Kimia \\ Pascasarjana Universitas Negeri Malang \\ Jalan Semarang 5, Malang 65145 \\ E-mail: shinta.amalia@gmail.com
}

\section{ABSTRAK}

\begin{abstract}
The purpose of this study was to find out: (1) differences in cognitive learning outcomes between students who use the problem posing learning model accompanied by discussion through Facebook and without Facebook; (2) the quality of questions formulated by students using the problem posing learning model accompanied by discussion through Facebook and without Facebook. This research uses quasi-experimental research design. The research sample consisted of 2 classes chosen randomly. Both classes use problem posing models in stoichiometry learning. The results showed: (1) the cognitive results of students in learning posing problems accompanied by discussions through Facebook were better than the cognitive results of students in learning posing problems accompanied by discussions without facebook; (2) there is no difference in the quality of the questions formulated by students in the two classes.
\end{abstract}

\begin{abstract}
Abstrak: Tujuan penelitian ini adalah untuk mengetahui: (1) perbedaan hasil belajar kognitif siswa antara yang menggunakan model pem-belajaran problem posing disertai diskusi melalui facebook dan tanpa facebook; (2) kualitas soal yang dirumuskan siswa antara yang menggunakan model pembelajaran problem posing disertai diskusi melalui facebook dan tanpa facebook. Penelitian ini menggunakan rancangan penelitian eksperimen semu. Sampel penelitian terdiri dari 2 kelas yang dipilih secara acak. Kedua kelas menggunakan model problem posing dalam pembelajaran stoikiometri. Hasil penelitian menunjukkan: (1) hasil kognitif siswa dalam pembelajaran problem posing disertai diskusi melalui facebook lebih baik dibandingkan hasil kognitif siswa dalam pembelajaran problem posing disertai diskusi tanpa facebook; (2) tidak ada perbedaan kualitas soal yang dirumuskan siswa pada kedua kelas.
\end{abstract}

Kimia sering dianggap sebagai mata pelajaran yang sulit, padahal ilmu kimia merupakan salah satu cabang terpenting dari ilmu alam (Sirhan, 2007). Selain itu kimia merupakan "inti ilmu alam" atau "ibu ilmu alam" (Jimoh, 2005). Salah satu materi kelas X yang dianggap sulit oleh siswa adalah materi stoikiometri, yaitu materi yang mempelajari perhitungan-perhitungan kimia. (Furio, Azcona, \& Guisasola, 2002) mengatakan bahwa konsep yang penting dalam kimia adalah konsep mengenai jumlah zat dan mol, tetapi siswa kesulitan dengan materi tersebut. Konsep mengenai jumlah zat dan mol adalah konsep yang dipelajari pada stoikiometri.

Penyebab utama sulitnya siswa memahami stoikiometri adalah rendahnya kemampuan berpikir mengenai perbandingan (proportional reasoning), padahal proportional reasoning adalah inti dari stoikiometri (Herron, 
1996). Menurut (Cetin \& Ertekin, 2011; Singh, Singh, \& Singh, 2008) proportional reasoning adalah kemampuan untuk membandingkan bagian-bagian dan menentukan bagian-bagian yang ekiva-len, tidak terbatas pada perbandingan dan bagian-bagian tetapi membangun hubung-an satu sama lain. Pada materi stoikiometri siswa harus memahami konsep-konsep penting, hubungan antara konsep tersebut, dan juga dapat menghitung perbandingan bagian-bagian yang terlibat dalam suatu reaksi atau pada suatu zat, semua materi tersebut memerlukan kemampuan berpikir proporsi (proportional reasoning).

Alternatif model pembelajaran yang sesuai untuk materi stoikiometri adalah problem posing, yaitu model pembelajaran yang menuntut siswa untuk merumuskan soal. Model problem posing mempunyai kelebihan dibandingkan pembelajaran yang hanya menuntut siswa mengerjakan latihan soal. Pada pembelajaran model problem posing siswa dituntut untuk merumuskan suatu soal. Pada saat siswa merumuskan soal, siswa harus menguasai konsep-konsep yang terlibat dan sudah dapat memperkirakan langkah-langkah penyelesaian soal tersebut. Materi stoikio-metri merupakan materi kimia yang menghubungkan banyak konsep, sehingga dalam merumuskan soal siswa mempunyai banyak pilihan untuk menentukan konsep yang akan dilibatkan.

Beberapa penelitian menunjukkan bahwa pembelajaran dengan menggu-nakan model problem posing memberikan hasil belajar yang lebih baik dibanding pembelajaran dengan ceramah. Penelitian yang dilakukan (Azhar, 2001) membuk-tikan bahwa pembelajaran stoikimetri dengan model problem posing memberikan pengaruh signifikan terhadap hasil belajar siswa. Hasil penelitian lain ten-tang penggunaan model problem posing, dilakukan pada pembelajaran biologi pokok bahasan ekosistem berupa penelitian tindakan kelas yang dilaksanakan pada siswa kelas VII SMP di Surakarta. Penelitian dilaksanakan dalam tiga siklus belajar yang masing-masing menggunakan model problem posing. Setiap akhir siklus bel-ajar dilakukan pengambilan nilai hasil belajar. Hasil penelitian menunjukkan bahwa ada peningkatan hasil belajar pada setiap siklus belajar seperti yang diungkapkan oleh (Hidayati, 2008).

Pembelajaran dengan model problem posing memerlukan waktu yang lebih banyak dibanding pembelajaran yang melibatkan latihan soal biasa. Penggunaan facebook sebagai sarana diskusi di luar kelas diduga layak digunakan mengingat banyaknya pengguna facebook saat ini. Hasil penelitian pada tahun 2007 oleh Pew Internet and American Life mengemukakan bahwa 48\% remaja menggunakan facebook lebih dari satu kali dalam sehari, 26\% menggunakan facebook satu kali dalam sehari, dan $22 \%$ beberapa kali dalam sehari (Munoz \& Towner, 2009). (Yang, Wang, Woo, \& Quek, 2011) menyatakan bahwa penggu-naan facebook untuk pembelajaran dapat meningkatkan motivasi belajar, rasa nya-man, dan hubungan antar siswa. Selain itu hasil penelitian yang dilakukan oleh Wang, et al.(tanpa tahun) menyimpulkan bahwa melalui facebook guru dapat me-nyimpan informasi, menukar informasi antar siswa, dan diskusi secara on line. Penelitian yang dilakukan (Kayri \& Cakir, 2010) menunjukkan bahwa ada potensi menggunakan facebook untuk belajar.

Berangkat dari uraian latar belakang di atas, dalam penelitian ini dikaji pengaruh penggunaan media facebook pada pembelajaran stoikiometri di kelas X dengan model problem posing. Rumusan masalah pada penelitian ini sebagai berikut:

a. Adakah perbedaan hasil kognitif materi stoikiometri antara siswa kelas X yang dibelajarkan dengan problem posing dan menggunakan facebook sebagai media interaksi di luar kelas dengan siswa yang belajar tanpa facebook di luar kelas?

b. Adakah perbedaan kualitas soal materi stoikiometri yang dirumuskan siswa antara yang menggunakan facebook sebagai media interaksi di luar kelas dengan siswa yang belajar tanpa facebook pada model pembelajaran problem posing di kelas X?

c. Bagaimana tingkat keaktifan belajar siswa kelas $\mathrm{X}$ yang belajar stoikiometri dengan bantuan facebook dibandingkan dengan siswa yang belajar stoikiometri tanpa bantuan facebook?

\section{METODE}

Populasi pada penelitian ini adalah seluruh siswa kelas X SMAN 1 Batu tahun ajaran 2010/2011 yang berjumlah 9 kelas, terdiri dari 305 siswa dengan rincian 114 siswa laki-laki dan 191 siswa perempuan. Sampel diambil dua kelas dari populasi yang relatif setara secara acak dan terpilih kelas X-4 sebagai kelas eksperimen, kelas X-5 sebagai kelas kontrol. Jumlah siswa kelas X-4 sebanyak 34 orang dengan rincian siswa laki-laki 12 orang dan siswa perempuan 22 orang. Jum-lah siswa pada kelas X-5 pun 34 orang dengan rincian siswa laki-laki 12 orang dan siswa perempuan 22 orang. Alur pelaksanaan penelitian disajikan pada Gbr 1.

Pada kelas eksperimen, di luar jam pembelajaran di kelas siswa diberi kesempatan untuk berdiskusi melalui media facebook. Pada kelas kontrol, di luar jam pembelajaran di kelas siswa berdiskusi langsung 
tanpa melalui facebook. Facebook yang digunakan untuk diskusi adalah facebook yang khusus dibuat baru oleh siswa. Interaksi dengan pihak lain yang tidak berkepentingan dihindarkan dengan cara nama siswa yang dicantumkan pada facebook didahului dengan kata tertentu seba-gai ciri kelas, dan seluruh anggota kelas eksperimen dilarang menambah teman pada facebook selain teman sekelas dan peneliti.

Setiap siswa dianjurkan minimal berinteraksi 1 kali melalui facebook di antara 2 pertemuan di kelas. Diskusi melalui facebook dilakukan secara mandiri, artinya setiap siswa berkewajiban mengajukan soal, menjawab soal, atau berkomen-tar mengenai materi stoikiometri pada "wall" peneliti atau dengan cara menulis pesan pada peneliti. Model pembelajaran yang digunakan di dalam kelas adalah model problem posing.

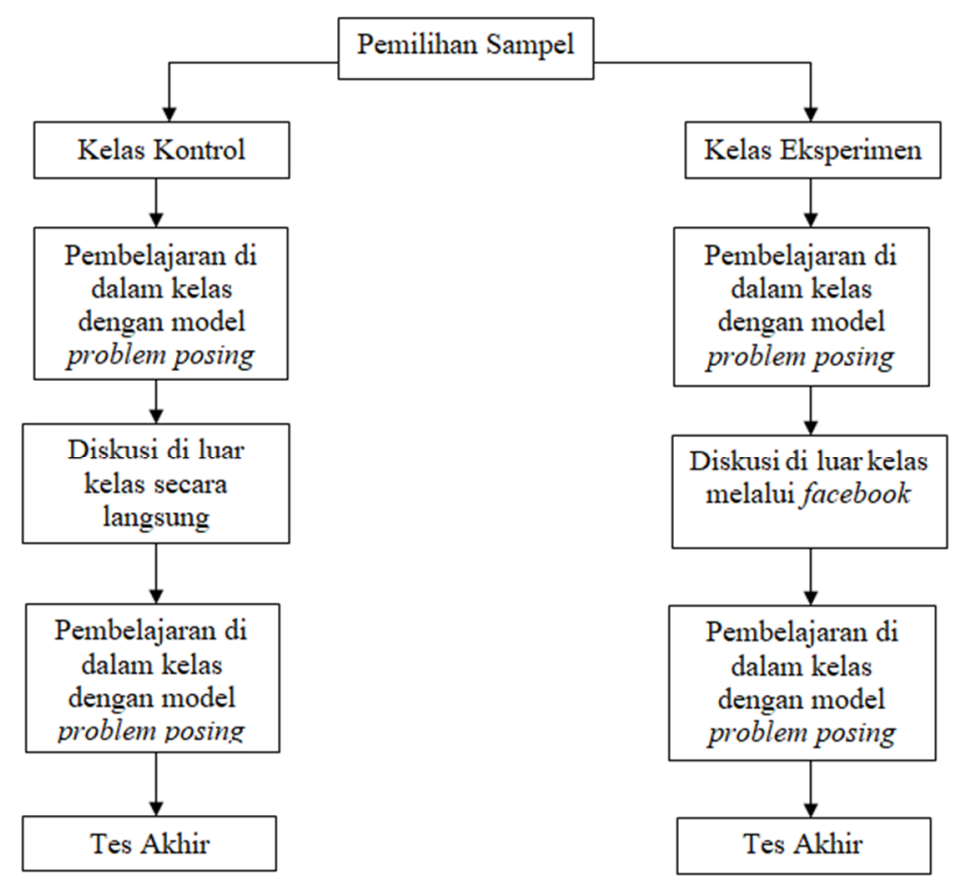

Gambar 1. Tahapan Pelaksanaan Penelitian

Pada kelas kontrol, untuk lebih mengefektifkan proses diskusi di luar kelas siswa dibagi menjadi 6 kelompok dengan jumlah siswa per kelompok 5-6 orang. Kelompok yang dibentuk bersifat heterogen dari prestasi belajar dan gendernya. Setiap kelompok diharuskan berdiskusi di luar kelas (di luar jam pelajaran) menge-nai materi yang dibicarakan sebelumnya di dalam kelas. Diskusi minimal dilakukan satu kali di antara dua pertemuan di dalam kelas. Waktu, tempat, daftar hadir, dan hasil diskusi setiap kelompok kontrol dicatat untuk dilaporkan. Bahan diskusi untuk kelas eksperimen dan kelas kontrol dibuat setara dan disiapkan oleh peneliti.

Setiap awal pembelajaran di kelas kontrol maupun kelas eksperimen, setelah penugasan diskusi di luar kelas dilakukan pembahasan mengenai materi yang telah didiskusikan di luar kelas. Pada kelas kontrol perwakilan tiap kelompok mempre-sentasikan hasil diskusi kelompok, sedangkan siswa lain memberikan tanggapan. Pada kelas eksperimen dibahas hal-hal yang menjadi masalah pada diskusi melalui facebook, siswa memberi tanggapan. Secara umum langkah pembelajaran pada kelas kontrol maupun kelas eksperimen dapat dilihat pada Gbr 2. 


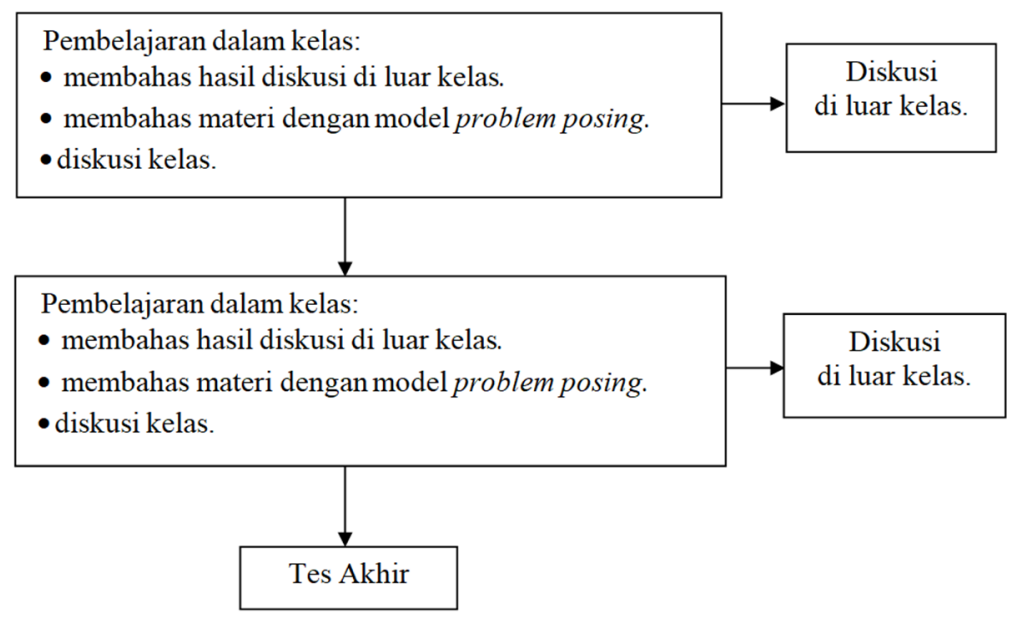

Gambar 2. Langkah Pembelajaran di Kelas

Selama proses pembelajaran di kelas dilakukan pengambilan data berupa kualitas soal yang dirumuskan siswa dan pengamatan keaktifan siswa selama proses pembelajaran, hasil belajar kognitif diperoleh melalui tes akhir.Penilaian kualitas soal yang dirumuskan siswa pada penelitian ini dinilai berdasarkan banyaknya konsep yang terlibat jika soal tersebut diselesaikan. Pada Tabel 1 disajikan rubrik tingkat kesulitan soal.

\begin{tabular}{|c|c|}
\hline Skor & Tingkat Kesulitan Soal \\
\hline 1 & melibatkan 1 konsep \\
\hline 2 & melibatkan 2 konsep \\
\hline 3 & melibatkan 3 konsep \\
\hline 4 & melibatkan 4 konsep \\
\hline 5 & melibatkan 5 konsep \\
\hline
\end{tabular}

Nilai kualitas soal dihitung dengan cara memberi skor pada setiap soal yang dirumuskan oleh siswa lalu nilai skor total yang diperoleh siswa di dalam satu bagi-an latihan soal dibandingkan dengan skor maksimal untuk latihan soal tersebut. Nilai kualitas soal secara keseluruhan/akhir pada materi stoikiometri didapat dengan cara menghitung nilai rata-rata kualitas soal selama pembelajaran. Berdasarkan data nilai kualitas soal yang dirumuskan siswa, nilai kualitas soal dikelompokkan ke da-lam kriteria sangat baik, baik, cukup, kurang. Kriteria baik didasarkan pada kriteria ketuntasan minimal di SMAN 1 Batu untuk mata pelajaran kimia yaitu 75. Pada Tabel 2 disajikan kriteria kualitas soal yang dirumuskan siswa. Untuk mengetahui adanya perbedaan kualitas soal yang dirumuskan siswa pada kedua kelas dilakukan uji-t.

Data keaktifan siswa diperoleh dengan mengamati keaktifan siswa selama proses pembelajaran baik pada kelas kontrol maupun kelas eksperimen. Setiap ke- giatan siswa diberi skor dengan kriteria seperti disajikan pada Tabel 3.

\begin{tabular}{cc}
\multicolumn{2}{c}{ Tabel 2. Kriteria Kualitas Soal } \\
\hline Rentangan Nilai & Kriteria \\
\hline $86-100$ & Sangat baik \\
$75-85$ & Baik \\
$60-74$ & Cukup \\
$\leq 59$ & Kurang \\
\hline
\end{tabular}

Tabel 3. Skor Keaktifan Siswa

\begin{tabular}{cc}
\hline Skor & Kegiatan Siswa \\
\hline 1 & Bertanya/menjawab yang melibatkan 1 konsep/mempresentasikan rumusan soal yang melibatkan 1 konsep \\
beserta penyelesaiannya
\end{tabular}




\begin{tabular}{|c|c|}
\hline 2 & $\begin{array}{c}\text { Bertanya/menjawab yang melibatkan } 2 \text { konsep/mempresentasikan rumusan soal yang melibatkan } 2 \text { konsep } \\
\text { beserta penyelesaiannya }\end{array}$ \\
\hline 3 & $\begin{array}{c}\text { Bertanya/menjawab yang melibatkan } 3 \mathrm{konsep/mempresentasikan} \mathrm{rumusan} \mathrm{soal} \mathrm{yang} \mathrm{melibatkan} 3 \text { konsep } \\
\text { beserta penyelesaiannya }\end{array}$ \\
\hline 4 & $\begin{array}{c}\text { Bertanya/menjawab yang melibatkan } 4 \text { konsep/mempresentasikan rumusan soal yang melibatkan } 4 \text { konsep } \\
\text { beserta penyelesaiannya }\end{array}$ \\
\hline 5 & $\begin{array}{c}\text { Bertanya/menjawab yang melibatkan } 5 \text { konsep/mempresentasikan rumusan soal yang melibatkan } 5 \text { konsep } \\
\text { beserta penyelesaiannya }\end{array}$ \\
\hline
\end{tabular}

Skor keaktifan yang diperoleh siswa selama pembelajaran dikelompokkan ke dalam kriteria sangat aktif, aktif, cukup aktif, kurang aktif. Pengelompokkan kriteria keaktifan dilakukan dengan cara menentukan skor maksimal yang diperoleh siswa sebagai kriteria sangat aktif, kemudian dari skor maksimal sampai minimal dibuat rentang menjadi 4 kriteria yaitu sangat aktif, aktif, cukup aktif, kurang aktif. Keak-tifan kelas secara umum diketahui dengan menghitung skor rata-rata keaktifan siswa.

Data kognitif hasil belajar diperoleh melalui tes akhir pada kelas eksperimen maupun kelas kontrol. Soal tes akhir terdiri dari 20 soal pilihan ganda (7 soal dalam Bahasa Inggris) dan 5 soal uraian. Soal pilihan ganda mempunyai nilai reliabilitas 0,44 yang diukur dengan Cronbach's Alpha, sedangkan soal uraian mempunyai nilai reliabilitas 0,55. Perbedaan hasil belajar kedua kelas diketahui melalui uji-t.

\section{HASIL}

Nilai hasil belajar siswa kelas FB sebanyak 26, 47\% sudah mencapai ketun-tasan, sedangkan kelas NFB sebesar $11,76 \%$ (Tabel 4 ).

\begin{tabular}{ccc}
\multicolumn{3}{c}{ Tabel 4. Nilai Hasil Belajar } \\
\hline Nilai & \% Siswa Kelas FB & \% Siswa Kelas NFB \\
\hline $0-44$ & 2,94 & 8,82 \\
$45-54$ & 2,94 & 26,47 \\
$55-64$ & 17,65 & 26,47 \\
$65-74$ & 50 & 26,47 \\
$75-84$ & 23,53 & 11,76 \\
$85-100$ & 2,94 & 0 \\
$\%$ Rata-rata & 26,47 & 11,76 \\
Tuntas $(>75)$ & & \\
\hline
\end{tabular}

Nilai hasil belajar rata-rata siswa kelas FB sebesar 69 dan kelas NFB sebesar 61 . Hasil pengujian dengan uji-t (signifikansi 5\%) memberikan data signifikansi (2-tailed) sebesar 0,001. Data t_tabel dengan $\alpha=5 \%(2$ ekor) memiliki nilai 1,96 sedangkan t_hitung memberikan hasil 3,47. Data di atas menunjukkan bahwa ada perbedaan yang signifikan antara hasil belajar siswa kelas FB dan kelas NFB, dan hasil belajar siswa FB lebih baik dari siswa NFB.

Analisa terhadap kemampuan menjawab soal pilihan ganda berbahasa Inggris untuk siswa kelas FB menunjukkan nilai rerata 30, sedangkan kemampuan menjawab soal berbahasa Indonesia menunjukkan nilai rerata 33. Pada siswa kelas NFB kemampuan menjawab soal pilihan ganda berbahasa Inggris menunjukkan nilai rerata 24, sedangkan kemampuan menjawab soal berbahasa Indonesia menun-jukkan nilai rerata 33. Data tersebut menunjukkan bahwa kemampuan siswa kelas FB untuk menjawab soal berbahasa Inggris lebih baik dari siswa kelas NFB, akan tetapi kedua kelas menunjukkan kemampuan yang sama dalam menjawab soal berbahasa Indonesia.

Nilai kualitas soal yang dirumuskan siswa dari kelas FB memberikan nilai rata-rata 43, sedangkan nilai rata-rata kualitas soal yang diperoleh siswa kelas NFB sebesar 36. Sebaran nilai kualitas soal yang dirumuskan disajikan pada Tabel 5.

Tabel 5. Persentase Rata-Rata Nilai Kualitas Soal

\begin{tabular}{cccc}
\hline \multicolumn{2}{c}{ Rentangan Nilai } & \% Siswa Kelas FB & \% Siswa Kelas NFB \\
\hline 0 & -10 & 8,8 & 11,8 \\
11 & -20 & 14,7 & 11,8 \\
21 & -30 & 8,8 & 14,7 \\
31 & -40 & 8,8 & 14,7 \\
\hline
\end{tabular}




\begin{tabular}{cccc}
\hline 41 & -50 & 17,7 & 23,5 \\
51 & -60 & 11,8 & 23,5 \\
61 & -70 & 20,6 & 0 \\
71 & -80 & 8,8 & 0 \\
81 & -90 & 0 & 0 \\
91 & -100 & 0 & 0 \\
\hline
\end{tabular}

Pengujian statistik uji-t (taraf signifikasi 5\%) terhadap nilai kualitas soal kedua kelas memberikan hasil signifikansi (2 tailed) 0,16 yang menunjukkan bahwa tidak ada perbedaan signifikan antara nilai kualitas soal yang diru-muskan siswa antara kelas FB dan NFB. Nilai t_tabel dengan $\alpha=5 \%$ (2 ekor) menunjukkan nilai 1,96 sedangkan t_hitung memberikan hasil 1,42, hasil ini pun menunjukkan tidak ada perbedaan signifikan antara nilai kualitas soal yang dirumuskan siswa pada kelas FB dan kelas NFB. Berdasarkan data di atas maka tidak ada perbe-daan signifikan antara nilai kualitas soal yang dirumuskan siswa pada kelas FB dan kelas NFB. Data kemampuan siswa kelas FB dan NFB untuk menjawab soal yang dirumuskan teman maupun dirumuskan sendiri disajikan pada Tabel 6 .

Nilai rata-rata kemampuan siswa kelas FB untuk menjawab soal yang dirumuskan sendiri memberikan hasil 65, sedangkan nilai rata-rata kelas NFB 56. Kemampuan siswa kelas FB untuk menjawab soal yang dirumuskan teman membe-rikan nilai rata-rata 61, sedangkan nilai rata-rata kelas NFB 59 . Nilai hasil ratarata ini menunjukkan bahwa kemampuan rata-rata siswa kelas FB untuk menjawab soal yang dirumuskan sendiri dan soal yang dirumuskan teman lebih baik daripada kemampuan siswa kelas NFB.

Tabel 6. Persentase Kemampuan Siswa Menjawab Soal

\begin{tabular}{ccccc}
\hline Rentang Nilai & $\begin{array}{c}\text { \% Siswa Kelas FB } \\
\text { Soal Rumusan } \\
\text { Sendiri }\end{array}$ & $\begin{array}{c}\text { Soal Rumusan } \\
\text { Teman }\end{array}$ & $\begin{array}{c}\text { \%oal Rumusan Kelas NFB } \\
\text { Sendiri }\end{array}$ & $\begin{array}{c}\text { Soal Rumusan } \\
\text { Teman }\end{array}$ \\
\hline $0-10$ & 11,8 & 2,9 & 29,4 & 20,6 \\
$11-20$ & 0 & 5,9 & 0 & 0 \\
$21-30$ & 2,9 & 5,9 & 5,9 & 8,8 \\
$31-40$ & 5,9 & 8,8 & 0 & 2,9 \\
$41-50$ & 20,6 & 23,5 & 11,8 & 14,7 \\
$51-60$ & 2,9 & 2,9 & 2,9 & 0 \\
$61-70$ & 0 & 5,9 & 2,9 & 0 \\
$71-80$ & 11,8 & 11,8 & 11,8 & 5,9 \\
$81-90$ & 14,7 & 14,7 & 5,9 & 11,8 \\
$91-100$ & 29,4 & 17,7 & 29,4 & 35,3 \\
\hline
\end{tabular}

Pengamatan terhadap keaktifan siswa selama pembelajaran menunjukkan bahwa keaktifan siswa pada kelas FB lebih baik dibandingkan keaktifan siswa kelas NFB. Skor maksimal keaktifan siswa di kelas FB sebesar 15, sedangkan skor keak-tifan siswa di kelas NFB hanya 8. Pada Tabel 7 disajikan persentase siswa pada ke-las FB dan NFB pada berbagai tingkat keaktifan.

Tabel 7. Persentase Siswa Pada Berbagai Tingkat Keaktifan

\begin{tabular}{cccc}
\hline Skor Keaktifan & $\begin{array}{c}\text { \% } \\
\text { Siswa pada Tingkat Keaktifan } \\
\text { Kelas } \\
\text { FB }\end{array}$ & $\begin{array}{c}\text { Kriteria } \\
\text { Kelas NFB }\end{array}$ & \\
\hline $0-3$ & 76,5 & 70,6 & Kurang Aktif \\
$4-7$ & 11,8 & 20,6 & Cukup Aktif \\
$8-11$ & 2,9 & 8,8 & Aktif \\
$12-15$ & 8,8 & 0 & Sangat Aktif \\
\hline
\end{tabular}

Berdasarkan persentase keaktifan siswa terlihat bahwa keaktifan siswa di kelas FB sebanyak 76,5\% berada pada kriteria kurang aktif, sedangkan siswa di kelas NFB sebanyak 70,6\%. Pada kriteria cukup aktif persentase siswa di kelas FB hanya 11,8\% sedangkan di kelas NFB sebanyak 20,6\%. Persentase dengan jumlah yang sama yaitu 8,8\% berada pada kriteria sangat aktif untuk siswa kelas FB dan kriteria aktif untuk siswa kelas NFB. Pengamatan keaktifan yang lebih terperinci selama pembelajaran menunjukkan bahwa skor 
keaktifan siswa yang tertinggi diperoleh pada kelas FB adalah 15, sedangkan skor keaktifan tertinggi siswa kelas NFB hanya 8. Skor rata-rata keaktifan siswa kelas FB sebesar 2,6 sedangkan skor rata-rata keaktifan siswa kelas NFB sebesar 2,3. Data tersebut menunjukkan bahwa secara umum keaktifan siswa di kelas FB maupun kelas NFB masih kurang aktif, meskipun keaktifan siswa di kelas FB sedikit lebih baik dibandingkan keaktifan siswa pada kelas NFB.

\section{PEMBAHASAN}

Ada beberapa alasan yang menyebabkan hasil belajar siswa yang meng-gunakan media facebook memberikan hasil yang lebih baik, diantaranya: (a) Diskusi lewat facebook lebih menarik sehingga siswa merasa tidak sedang belajar pada saat berdiskusi melalui facebook, (b) Tidak ada rasa canggung untuk bertanya hal-hal yang tidak dipahami mengingat tidak ada interaksi secara langsung. Seperti yang diungkapkan (Harvard, Du, \& Olinzock, 2007) bahwa diskusi on line akan memaksa siswa untuk belajar, sehingga kendala tidak percaya diri dan kurang motivasi dapat teratasi, (c) Diskusi yang dilakukan melalui facebook ti-dak terikat oleh waktu, siswa dapat melaku-kannya kapan saja. Seperti yang diungkap-kan (Wojnar \& Uden, 2005) bahwa diskusi on line lebih produktif dan memberikan hasil belajar lebih baik, (d) Tempat untuk melakukan diskusi lebih flek-sibel, dapat dilakukan di mana saja tidak ter-batas di lingkungan sekolah karena siswa da-pat membuka facebook melalui handphone (hampir semua siswa memiliki handphone), (e) Hasil diskusi masih bisa diakses kapanpun, sehingga dapat dijadikan bahan belajar de-ngan waktu fleksibel. Hal ini sesuai dengan yang diungkapkan oleh (Kayri \& Cakir, 2010) bahwa melalui facebook, materi pel-ajaran dapat disimpan sehingga siswa dapat mengakses informasi, jawaban atas pertanya-anpertanyaan sebelumnya dengan teman se-kelas, dan akan mencegah mengajukan perta-nyaan yang sama, (f) Melalui facebook siswa dapat belajar dari ke-keliruan atau jawaban benar yang diajukan siswa lain.

Diskusi yang terjadi melalui facebook me-mungkinkan terjadi pengajaran oleh teman sebaya, sehingga pengajaran lebih efektif. Hal ini sejalan dengan yang diungkapkan (Slavin, 2006) yang menyatakan bahwa pengajaran oleh teman diantara siswa dengan usia yang sama dapat lebih efektif .

Rendahnya nilai kemampuan siswa merumuskan soal membuktikan bahwa merumuskan soal merupakan proses pembelajaran yang lebih tinggi daripada me-nyelesaikan soal, karena untuk merumuskan soal diperlukan kemampuan untuk menganalisis kondisi yang diberikan. Hal ini sejalan dengan yang diungkapkan Mestre ((Pittalis, Christou, Mousoulides, \& Pitta-Pantazi, 2004) yang menyatakan bahwa problem po-sing adalah kemampuan intelektual yang lebih tinggi dibanding problem solving.

Nilai kemampuan siswa untuk menjawab soal secara umum lebih tinggi dibandingkan nilai kemampuan siswa untuk merumuskan soal, hal ini membukti-kan bahwa kemampuan untuk merumuskan soal merupakan kemampuan yang lebih kompleks dibanding kemampuan menjawab soal, seperti yang diungkapkan Mestre (Pittalis et al., 2004). Nilai kemampuan menjawab soal yang lebih tinggi bagi siswa kelas FB dibanding siswa kelas NFB menunjukkan bahwa face-book dapat digunakan untuk membantu proses pembelajaran. Hasil penelitian ini sesuai dengan yang diungkapkan oleh (Wang, Woo, \& Quek, 2009)) yang menyatakan bahwa facebook mempunyai potensi besar untuk pembelajaran. Menurut Asen (McKenzie, 2005) ada beberapa kriteria teknologi dapat digunakan untuk pembelajaran diantaranya, (a) Siswa terlibat dalam tugas yang menantang untuk perkembangan intelektual. Facebook memenuhi kriteria ini karena dalam proses diskusi di luar kelas, siswa diberikan kebebasan seluas-luasnya untuk merumuskan pertanyaan/memberi jawaban/mengajukan pertanyaan, (b) Ada pengawasan dari guru mengenai berlangsungnya pembelajaran. Pada pene-litian ini semua kegiatan siswa berdiskusi melalui facebook dapat teramati kare-na semua siswa sudah menjadi "teman" peneliti, (c) Siswa mengkomunikasikan kemampuannya selama pembelajaran. Diskusi yang terjadi melalui facebook memungkinkan siswa mengkomunikasikan kemampu-annya melalui jawaban soal/merumuskan pertanyaan atau pun bertanya halhal yang belum dipahami, (d) Siswa didukung untuk memberikan ide-ide pribadi dan terlibat proses pembelajaran. Proses diskusi yang terjadi melalui facebook sangat memenuhi kriteria ini.

Keaktifan siswa dalam pembelajaran di kelas FB yang sedikit lebih baik dibanding keaktifan siswa di kelas NFB menunjukkan bahwa penggunaan facebook dapat meningkatkan motivasi belajar siswa, sehingga keaktifan siswa di kelas lebih baik. Hasil penelitian ini sejalan dengan yang diungkapkan oleh Leu (Slavin, 2006) yang menyatakan bahwa pemakaian program komputer untuk pembelajaran dapat meningkatkan motivasi belajar yang tadinya membosankan. Pada penelitian ini tidak secara khusus menggunakan komputer, tetapi media face-book yang dapat diakses dengan komputer, laptop, maupun handphone. Media 
facebook dapat menanggulangi kebosanan siswa dalam pembelajaran. Selain itu (McGill \& Bax, 2005) menyatakan bahwa pembelajaran yang melibatkan peng-gunaan teknonogi internet memungkinkan siswa berperan lebih aktif dibanding pembelajaran tradisional. Hasil penelitian ini menunjukkan bahwa pemakaian face-book dapat meningkatkan keaktifan pembelajaran di kelas karena motivasi belajar siswa menjadi lebih baik dan pembelajaran tidak membosankan.

\section{SIMPULAN DAN SARAN}

\section{Simpulan}

Ada perbedaan hasil kognitif materi stoikiometri antara siswa kelas $\mathrm{X}$ yang dibel- ajarkan dengan problem posing dan menggunakan facebook sebagai media interaksi di luar kelas dengan siswa yang belajar tanpa facebook di luar kelas. Siswa yang berdiskusi melalui facebook memberikan hasil kognitif rerata 69 sedangkan siswa yang berdiskusi tanpa facebook memberikan hasil kognitif rerata 61 . Tidak ada perbedaan kualitas soal materi stoikiometri yang dirumuskan siswa antara yang menggunakan facebook sebagai media interaksi di luar kelas dengan siswa yang belajar tanpa facebook pada model pembelajaran problem posing di kelas X. Tingkat keaktifan belajar siswa kelas $\mathrm{X}$ yang belajar stoikiometri dengan bantuan facebook sedikit lebih aktif (rerata 2,6) dibandingkan keaktifan siswa tanpa face-book sebagai media diskusi di luar kelas (rerata 2,3), walaupun keaktifan siswa di kedua kelas masih dalam kriteria kurang aktif.

\section{SARAN}

Penggunaan media facebook untuk diskusi di luar kelas layak digunakan untuk membantu proses pembelajaran di kelas, melalui penggunaan facebook siswa tidak merasa canggung karena tidak ada interaksi langsung. Penggunaan model problem posing dalam pembelajaran di kelas akan lebih baik jika disertai dengan proses diskusi di luar kelas, karena proses diskusi di luar kelas dapat menanggulangi terbatasnya waktu pembelajaran di dalam kelas. Subyek penelitian sebaiknya dikondisikan terlebih dahulu terhadap model pembel-ajaran problem posing, karena di dalam pembelajaran kimia selain mengerjakan soal siswa perlu dilatih untuk membuat soal terutama yang mendorong kemampuan berpikir tingkat tinggi.

Untuk penelitian lebih lanjut perlu diadakan kajian awal tentang minat subyek pene-litian terhadap materi ajar (kimia) sehingga dapat diketahui dengan lebih akurat pengaruh penggunaan facebook terhadap hasil belajar, terutama terhadap kualitas soal dan keaktifan siswa selama proses pembelajaran di kelas. Boleh jadi bagi subyek penelitian yang berminat terhadap kimia, kualitas soal dan keaktifannya akan jauh lebih tinggi jika menggunakan facebook.

\section{DAFTAR RUJUKAN}

Azhar, A. (2001). Keefektifan Pendekatan Problem Posing dan Deskripsi Kemampuan Problem Posing Siswa pada Pembelajaran Stoikiometri. Universitas Negeri Malang.

Cetin, H., \& Ertekin, E. (2011). The relationship between eighth grade primary school students' proportional reasoning skills and success in solving equations. International Journal of Instruction, 4(1).

Furio, C., Azcona, R., \& Guisasola, J. (2002). The learning and teaching of the concepts 'amount of substance'and 'mole': A review of the literature. Chemistry Education Research and Practice, 3(3), 277-292.

Harvard, B., Du, J., \& Olinzock, A. (2007). Task-orientation online discussion: A practical model for student learning. In Integrating information \& communications technologies into the classroom (pp. 154-166). IGI Global.

Herron, J. D. (1996). The Chemistry Classroom: Formulas for Successful Teaching. Washington, DC: American Chemical Society.

Hidayati, R. N. (2008). Aplikasi Pembelajaran Problem Posing dalam Meningkatkan Hasil Belajar Biologi Pokok Bahasan Ekosistem pada Siswa Kelas VIIe SMP Muhammadiyah 5 Surakarta Tahun Ajaran 2007/2008. Surakarta: Universitas Muhammadiyah Surakarta.

Jimoh, A. T. (2005). Perception of difficult topics in chemistry curriculum by students in Nigeria secondary schools. Ilorin Journal of Education, 24, 71-78.

Kayri, M., \& Cakir, O. (2010). An applied study on educational use of Facebook as a Web 2.0 tool: The sample lesson of computer networks and communication. ArXiv Preprint ArXiv:1009.0402.

McGill, T., \& Bax, S. (2005). Learning IT: where do lecturers fit? International Journal of Information and Communication Technology Education (IJICTE), 1(3), 36-46.

McKenzie, W. (2005). Multiple intelligences and instructional technology. ISTE (Interntl Soc Tech Educ). 
Munoz, C., \& Towner, T. (2009). Opening Facebook: How to use Facebook in the college classroom. Society for Information Technology \& Teacher Education International Conference, 2623-2627. Association for the Advancement of Computing in Education (AACE).

Pittalis, M., Christou, C., Mousoulides, N., \& Pitta-Pantazi, D. (2004). A structural model for problem posing. Proceedings of the 28th Conference of the International Group for the Psychology of Mathematics Education, 4, 49-56.

Singh, M., Singh, B., \& Singh, K. (2008). The influence of emotional intelligence and learning style on student's academic achievement/Baljinder Singh Maghar Singh and Kuldip Singh. Social and Management Research Journal, 5(2), 2536.

Sirhan, G. (2007). Learning difficulties in chemistry: An overview.

Slavin, R. E. (2006). Educational Psychologhy Theory and Practice (8th ed.). United States of America: Pearson Education.

Wang, Q. Y., Woo, H. L., \& Quek, C. L. (2009). Affordances of Facebook for collaborative learning. Asian Journal of Educational Research and Synergy, 1(1), 99-109.

Wojnar, L., \& Uden, L. (2005). Group process \& trust in group discussion. International Journal of Information and Communication Technology Education (IJICTE), 1(1), 55-68.

Yang, Y., Wang, Q., Woo, H. L., \& Quek, C. L. (2011). Using Facebook for teaching and learning: a review of the literature. International Journal of Continuing Engineering Education and Life Long Learning, 21(1), 72-86. 